\title{
The Serum Selenium Level, the Activity of Some Selenodependent Enzymes and the Lipid Profile in Childhood Obesity
}

\author{
ALEXANDRA GABRIELA CATIANIS, BOGDANA VIRGOLICI*, \\ CARMEN BEATRICE DOGARU, LAURA ANCA POPESCU, DANIEL MIRICESCU, \\ ALEXANDRA TOTAN, HORIA MARIUS VIRGOLICI, MARIA MOHORA \\ Carol Davila University of Medicine and Pharmacy, 8 Eroilor Sanitari Blvd., 050474, Bucharest, Romania
}

\begin{abstract}
Oxidative stress and dyslipidemia are present in childhood obesity. Selenoproteins are important antioxidants. Glutathione peroxidase and thioredoxin reduce the level of peroxides while the conversion of the tyroid hormon T4 to T3 needs also a selenoenzyme. Selenium deficiency can reduce the selenoproteins activity. The aim of this study was to determine the serum: selenium (Se), thioredoxin level (Trx) and activity of glutathione peroxidase (GPx) in obese children with dysmetabolism. The lipid profile, the hormones (free T4 and TSH), serum Se, serum Trx and GPx activity and atherogenic indexes (TG/HDLc, total cholesterol/HDLc, apoB/apoA-I) were determined in 20 healthy children (1016 years old) versus 41 overweight/obese children, same age, in an observational study. Spectrophotometer and ELISA methods were used. The GPx activity and the serum Se level had similar values in the studied groups, while the serum Trx level was lower in the obese children. The GPx activity was positively correlated with atherogenic indexes, negatively correlated with apo A-I ( $r=-0.74)$ and Se was positively correlated with apo B $(r=0.52)$. The obese children had TSH and freeT4 in the normal range, but freeT4 was significantly higher in comparison with the values observed in the normal weight children. In conclusion, in childhood obesity, the normal serum range values for selenium or for selenium dependent proteins can "hide" a dysmetabolism of selenium because there are significant differences for the values of these parameters versus the ones from normal weight children. In childhood obesity, serum GPx activity and selenium values were strongly correlated with the atherogenic indexes.
\end{abstract}

Keywords: childhood obesity, selenium, oxidative stress, atherogenesis

\section{Introduction}

According to WHO criteria, in Romania, almost one in four children was overweight or obese between 2006 and 2015 [1]. Obesity increases the risk of metabolic syndrome, dyslipidemia, insulin resistance, cardiovascular diseases, type II diabetes, and cancer [2,3]. Oxidative stress is one of the main molecular mechanisms involved in the development of obesity associated complications [4].

Even in young subjects, the abdominal type obesity is characterized by accumulation of intervisceral fat [5]. Excessive visceral fat releases cytokines, such as tumor necrosis factor-alfa (TNF-alfa) and interleukin 6 (IL-6) and subsequent, the systemic oxidative stress and inflammation are increased [4,6]. Excessive visceral adiposity alters metabolic pathway of very low density lipoprotein cholesterol (VLDL) and secondary, results on higher levels of low density lipoprotein (LDL) particles. Oxidized LDL particles are formed in the systemic oxidative stress medium and these particles are more aggressive on vascular endothelium and represent a risk factor for atherosclerosis [7].

Laboratory studies suggest that selenium (Se) plays a role in the pathophysiology of obesity due to its properties as an antioxidant and anti-inflammatory factor [8,9]. Selenium is an essential component of several antioxidant enzymes required for normal health, as glutathione peroxidase (GPx) and tioredoxin reductase (TrxR) [10]. Glutathione peroxidase 3 is the main extracellular isoenzyme of the glutathione peroxidase family (GPx). It is a tetrameric enzyme and each monomer contains a selenium

\footnotetext{
*email:hvirgolici@yahoo.com
} 
atom in the form of selenocysteine. This antioxidant enzyme, GPx acts on $\mathrm{H}_{2} \mathrm{O}_{2}$ and on phospholipid hydroperoxides and transform them into harmless products. The thioredoxin system consists of thioredoxin (Trx), the enzyme thioredoxin reductase (TrxR) and NADPH. Thioredoxin acts as a specific electron donor for peroxidases. Thioredoxine reductase (TrxR), a selenoprotein belongs to the category of proteins with redox activity and catalyse the reaction for Trx recovery $[11,12]$.

It is known that GPx and paraoxonase are major HDL-associated antioxidant enzymes [13]. In experimental studies it was demonstrated that Se deficiency leads to up regulation of apoB expression [14] and also, that low GPx activity and low Trx level are associated with trombosis $[15,16]$. Taken together, Se has a protective role against atherosclerosis [17,18].

The aim of this study was to determine the serum: selenium (Se), thioredoxin level (Trx) and activity of glutathione peroxidase (GPx) in overweight and obese children and to correlate their values with biomarkers of dyslipidemia.

\section{Materials and methods}

A total of 41 obese children (10-16 years old), and 20 healthy lean children (control group), same age, were enrolled in an observational study. Children with a medical history of taking corticosteroids, renal and/or endocrine disease, acute or chronic inflammation were excluded. All subjects were nonsmokers. The study protocol was approved by the Ethical Commission of "Carol Davila" University of Medicine, Bucharest and a written informed consent was obtained from each parent.

\subsection{Clinical characteristics}

Anthropometric measurements: weight, height, waist circumference (WC) were assessed. The BMI was calculated as the ratio between weight $(\mathrm{kg})$ divided by square height $\left(\mathrm{m}^{2}\right)$. Overweight is defined as 85-95th BMI percentile and obesity as $\geq 95$ th BMI percentile.

\subsection{Biochemical measurements}

Fasting blood samples were collected and stored in a sealed plastic bag in a dry and cool condition under room temperature until measurement. The usual plasma variables were measured by using an automatic analyzer HITACHI and kits with standard methods from Diasys (Germany). Low-density lipoprotein-cholesterol (LDL-C) was calculated according to the Friedewald equation [19].

Plasma Se concentration was measured by atomic absorption spectrophotometry, using AAnalyst 800 Perkin Elmer apparatus, integrated flame \& graphite furnace type, controlled by computer, equipped with a selenium cathode tube, autosampler, dehydrator using argon.

Plasma GPx level was determined by an UV method based on that of Paglia and Valentine [20]. GPx catalyses the oxidation of GSH by Cumene Hydroperoxide. In the presence of Glutathione Reductase and NADPH the oxidised Glutathione (GSSG) is immediately converted to the reduced form with a concomitant oxidation of NADPH to NADP+. GSH-Px activity is measured by the decrease in absorbance at $340 \mathrm{~nm}$ (Kit RANSEL).

Thioredoxin was determined by the enzyme-linked immunosorbent assay, ELISA (Thioredoxin Reductase Assay Kit, batch number 70463, BioVision, USA), by the clinical laboratory ALCOS 99 S.R.L. TSH and FT4 were determined by the ELISA enzyme immunoassay, in the analysis laboratory of the Emergency Clinical Hospital for Children "Grigore Alexandrescu" (RomGerM Laboratories).

The source of variation between the lean children and the obese children was assessed by the unpaired Student t-test. The Pearson correlation coefficient was calculated and the threshold for significance was set at $\mathrm{p}<0.05$.

\section{Results and discussions}

Dyslipidemia, inflammation and the oxidative stress are linked pathogenic mechanisms in obesity and atherosclerosis and they act in a vicious circle [12]. Data literature emphasize that dyslipidemia is present in more than half of the obese and overweight children, and the pattern of the dyslipidemia is 
usually, with high triglycerides and low HDLc [21]. In our study, the HDLc levels were similar between the studied groups, but the serum triglycerides and each atherogenic index, calculated as a ratio (TG/HDLc, total cholesterol/HDLc, apoB/apoA-I) were highly increased in the obese children versus the control.

Nowadays, the research on lipid-transporting apolipoproteins is on focus. ApoB transports the all potentially atherogenic particles: very low-density lipoprotein (VLDL), intermediate-density lipoprotein (IDL) and LDL particles. ApoA-I transports and acts as the major antiatherogenic protein and is present only on the HDL particles surface [22]. One molecule of apoB exists per lipoprotein particle. Thus, in fasting plasma, the quantity of apoB predicts the number of LDL and VLDL particles [23,24]. Also, apolipoprotein $\mathrm{B}(\mathrm{apoB})$ assures the interaction between LDL and LDL receptor [25]. There are researchers who consider that serum levels of apolipoprotein A-I (ApoA-I), apolipoprotein B (ApoB) and of ApoB/ApoA-I ratio are more informative indicators of cardiovascular disease than conventional serum lipids.

Several studies suggested that the tyroid hormone, triiodotyronine, T3 is directly involved in the regulation of LDL-R and apoB expression [26,27]. Also, it is known that by 5'-deiodination, in peripheral tissues, major amount of T3 is produced from T4 [28]. The enzyme responsible for deiodination is a selenoprotein which activity decreases during selenium deficiency $[29,30]$.

In our study, the obese and nonobese children had similar values of TSH. In the obese children, the free serum T4 level was in the normal range, but significantly higher than in the normal weight ones. Free T3, it wasn't measured. It is hard to say if the differences for free T4, between the obese and the control children are due to a weak function of the enzyme involved in deiodination, in obese children [28]. The multiple correlations between higher levels of triglycerides, apoB, and lower levels for albumin, selenium, free T3 and unchanged level for TSH were described, also, in another disease, like in euthyroid sick syndrome in maintenance hemodialysis patients [31].

The antioxidant defence system depends on environmental factors and on nutrient intake. Selenium is known as a mineral involved in decreasing the oxidative stress and in reducing cellular membranes lesions. Besides its anti-inflammatory and antioxidative capacities, Selenium can regulate adipogenesis via PPAR (peroxisome proliferator activated receptors) [32].

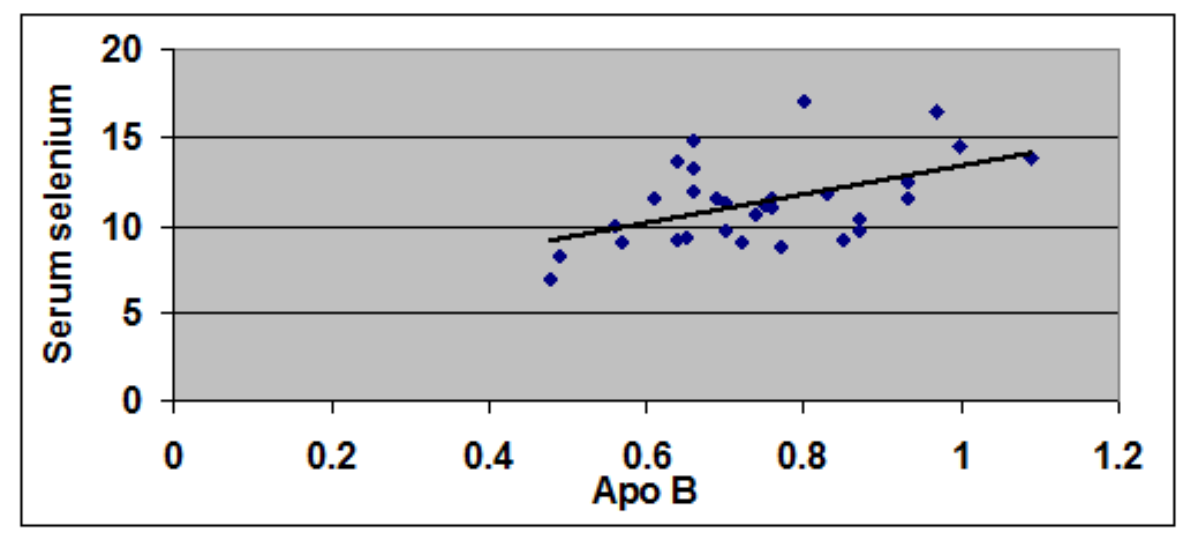

Figure 1. Correlation between serum selenium and apo B ratio

In our study, selenium had similar values in the studied groups and it was positively correlated with apo $\mathrm{B}(\mathrm{r}=0.52, \mathrm{p}<0.05)$ (Figure 1$)$. The influence of selenium metabolism on dyslipidemia and oxidative stress was more studied in experimental studies and less on clinical ones. In an experimental study done on Sprague Dawley rats the researchers demonstrates that Se deficiency leads to up regulation of apoB expression during experimental hypercholesterolemia [14]. In obese mice, Lee at al. demonstrated that "defective GPx3 expression in adipose tissue is associated with reduced systemic GPx activity and increased oxidative stress" [33]. It seems that hypoxia and inflammation in the adipose tissue have an important contribution for the down-regulation of GPx3 inside the tissue. But, the serum level of GPx3 
depends on its adipose tissue's level. In our study, the serum GPx activity had similar values in the studied groups. We demonstrated that in the obese children, the enzyme activity was positively correlated with TG/HDL ratio $(\mathrm{r}=0.54, \mathrm{p}<0.05)$ (Figure 2$)$ and with cholesterol/HDL ratio $(\mathrm{r}=0.34$, $\mathrm{p}<0.05)$. Also, apo B level was positively correlated with serum $\mathrm{Se}(\mathrm{r}=0.52, \mathrm{p}<0.05)$, while apo A1 level was negatively correlated with GPx activity $(r=-0.74, \mathrm{p}<0.05)$ (Figure 3).

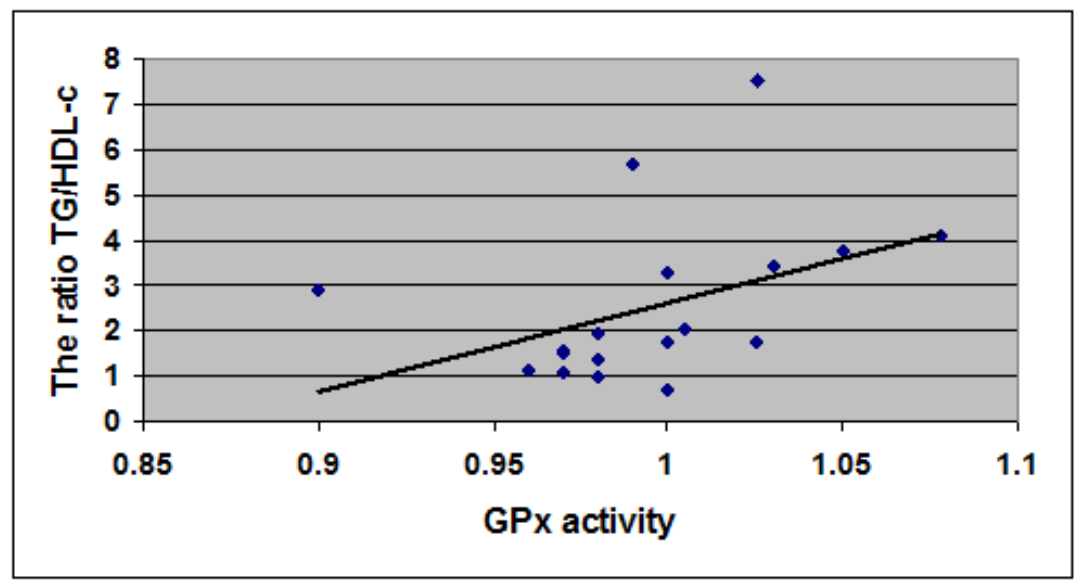

Figure 2. Correlation between the GPx activity and the TG/HDL-c ratio

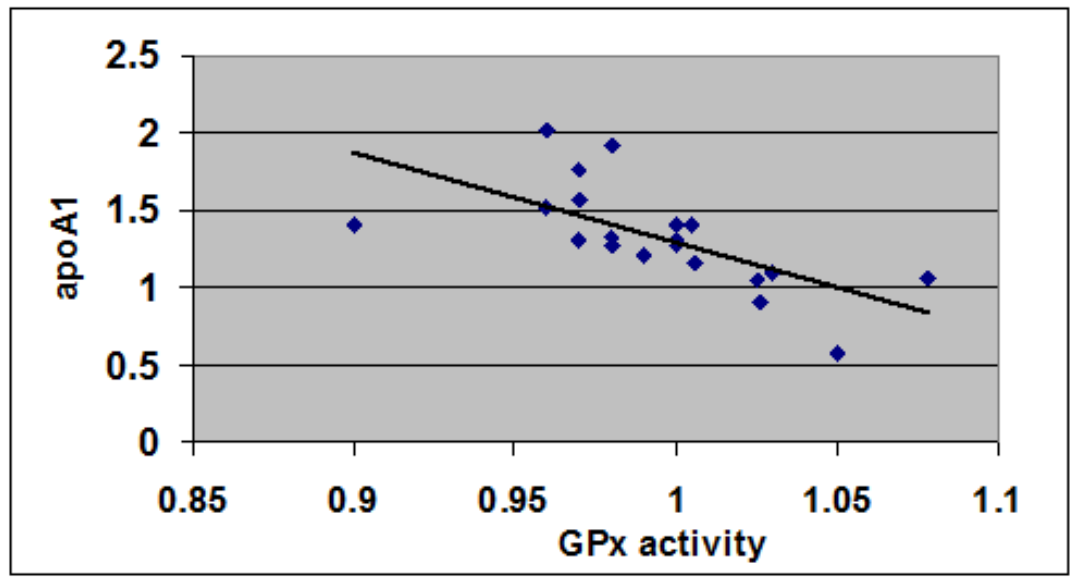

Figure 3. Correlation between apoA1 and Gpx activity

Our results on obese children are similar with those observed in obese and overweight adults $(n=133)$ from central Mexico. In 2012, this was the first clinical study, which demonstrated that GPx3 activity was correlated with the TG/HDLc index and insulin sensitivity. The authors considered that GPx3 undergoes changes in its messenger RNA (mRNA) expression in obesity and the stage (severity) of the disease is important. So it is a great task to get a proper interpretation of GPx activity. The enzyme is either induced or repressed, according to the factors from the medium [34]. In overweight and obese children, like those involved in our study, a weak systemic and local (in adipose tissue) inflammatory and oxidative stress status were described [21].

Data literature, showed that in severe diseases, characterized by increased oxidative stress, like end stage renal disease ESRD patients, marked reduction of serum apoA-1 were associated with low plasma paraoxonase and glutathione peroxidase (GPx) activities and reduced HDL-cholesterol level [35]. It was demonstrated that low activity of the enzyme GPx increases the risk of trombosis and reduce NO (nitric oxide) [15]. 


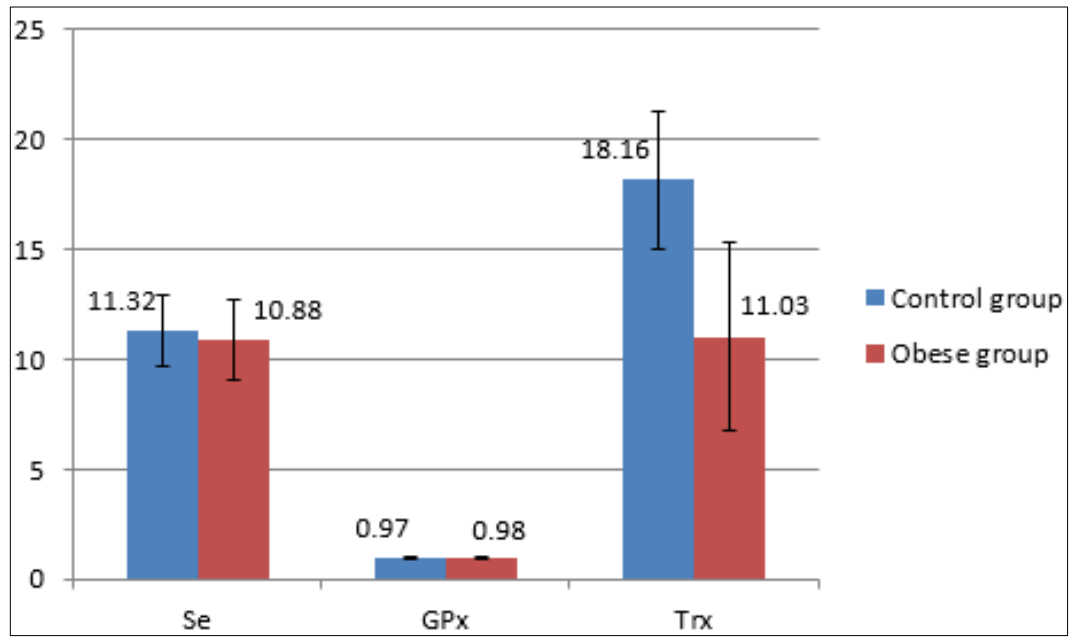

Figure 4. The comparison of the average values for serum selenium,

$\mathrm{Se}(\mu \mathrm{g} / \mathrm{dL})$, serum glutathione peroxidase (GPx) activity (U/mg protein) and serum thioredoxin level Trx (ng/g) for the obese group versus the control group.

Only for the Trx levels the differences were statistically significant $(p<0.05)$

Trx is another protein, involved in thrombosis, and its level can be indirectly influenced by selenium level. An endothelial prothrombotic phenotype in mouse models was explained by downregulation of thioredoxins [16]. The level of Trx depends on the activity of TrxR (thioredoxin reductase - a selenoprotein). When the TrxR has low activity, the recovery of Trx is weak. In our study, the thioredoxin Trx had a low value in obese versus control children (Figure 4).

Table 1. The average values and the standard deviation values for the studied parameters

\begin{tabular}{|c|c|c|c|}
\hline Parameters & Control group & Obese & $p$ \\
\hline Cholesterol mg/dL & $134.46 \pm 16,39$ & $177.2 \pm 34.3$ & $<0.01$ \\
\hline Triglycerides $\mathrm{mg} / \mathrm{dL}$ & $68.4 \pm 28.7$ & $110.25 \pm 52.6$ & $<0.001$ \\
\hline HDL-C mg/dL & $51.37 \pm 12.9$ & $53.38 \pm 12.9$ & Ns \\
\hline LDL-C mg/dL & $83.7 \pm 7.7$ & $104.23 \pm 30.4$ & $<0.03$ \\
\hline apoA & $1.20 \pm 0.15$ & $1.34 \pm 0.26$ & $\mathrm{Ns}$ \\
\hline Apo B & $0.51 \pm 0.03$ & $0.74 \pm 0.15$ & $<0.01$ \\
\hline apoB/apoAI & $0.43 \pm 0.04$ & $0.53 \pm 0.1$ & $<0.01$ \\
\hline $\mathrm{Col} / \mathrm{HDL}$ & $3.23 \pm 0.67$ & $3.38 \pm 0.803$ & Ns \\
\hline $\mathrm{Tg} / \mathrm{HDL}$ & $1.15 \pm 0.59$ & $1.90 \pm 0.91$ & 0,05 \\
\hline Uric Acid mg/dL & $3.48 \pm 0.5$ & $5.8 \pm 1.44$ & $<0.002$ \\
\hline GGT (UI/l) & $13.85 \pm 1$ & $16.06 \pm 5.03$ & Ns \\
\hline Glycemia mg/dL & $85.2 \pm 3.4$ & $86.2 \pm 7.5$ & Ns \\
\hline ALT(UI/l) & $13.07 \pm 2$ & $18.8 \pm 7.5$ & $<0.05$ \\
\hline Creatinine $\mathrm{mg} / \mathrm{dL}$ & $0.80 \pm 0.15$ & $0.75 \pm 0.16$ & Ns \\
\hline Bilirubin mg/dL & $0.55 \pm 0.29$ & $0.5 \pm 0.31$ & Ns \\
\hline Fibrinogen $\mathrm{g} / \mathrm{L}$ & $3.23 \pm 0.12$ & $3.26 \pm 0.12$ & Ns \\
\hline $\mathrm{CRP} \mathrm{mg} / \mathrm{dL}$ & $0.95 \pm 0.35$ & $2.3 \pm 1.02$ & $<0.04$ \\
\hline Ceruloplasmin $\mathrm{mg} / \mathrm{dL}$ & $29.82 \pm 3$ & $34.02 \pm 5.33$ & $<0.02$ \\
\hline Albumin g/dL & $4.21 \pm 0.4$ & $3.93 \pm 0.31$ & $<0.002$ \\
\hline Free $\mathrm{T} 4(\mathrm{pg} / \mathrm{mL})$ & $12.94 \pm 0.71$ & $14.63 \pm 1.44$ & $<0.001$ \\
\hline TSH (mIU/mL) & $2.27 \pm 0.88$ & $2.96 \pm 1.57$ & Ns \\
\hline
\end{tabular}

This study has some limitation because of the small number of subjects involved. But it underlines that levels in the normal range for a parameter, at the upper or the lower limit, in the obese subjects can be significantly different from those of normal weight children. There is a paucity of data about selenium metabolism and selenoproteins in obese children and this is a pilot study which shows the importance of this topic.

Selenium is "one of the most powerful antioxidative trace elements". In adults it was shown that low selenium status has been associated with increased risk of mortality, poor immune function, cognitive 
decline, increased risk for autoimmune thyroid disease. The selenoprotein thioredoxin reductase (TrxR) is an essential antioxidant enzyme that reduces Coenzyme Q10. This coenzyme is vital for mitochondrial respiratory chain, whose main function is to produce adenosine triphosphate (ATP), and it has an important place at the crosslinking of the sugar and lipid metabolism [36, 37].

In obese children, in order to prevent the young adulthood dysmetabolism, the physicians have to prescribe diets rich in selenium, like lentils, beef and eggs. In the future, the doses of selenium intake from supplemments will be established.

\section{Conclusions}

The serum selenium level, the lipid profile and the selenoprotein enzymes activities are linked. Selenium is a piece of a" puzzle" which has a place in oxidative stress, in dyslipidemia, inflammation and thrombosis "picture". The relation cause or effect is not well understood, but a bidirectional relation is common.

\section{References}

1.CHIRITA-EMANDI, A., BARBU, C.G., CINTEZA, E.E., CHESARU, B.I., GAFENCU, M., MOCANU, V., PASCANU, I.M., TATAR, S.A., BALGRADEAN, M., DOBRE, M., FICA, S.V., ICHIM, G.E., POP, R., PUIU, M., Overweight and Underweight Prevalence Trends in Children from Romania - Pooled Analysis of Cross-Sectional Studies between 2006 and 2015, Obesity Facts, 2016 Jun; 9(3): 206-220.

2.CEFALU, W.T., BRAY, G.A., HOME, P.D., GARVEY, W.T., KLEIN, S., PI-SUNYER, F.X., HU, F.B., RAZ, I., VAN GAAL, L., WOLFE, B.M., Advances in the science, treatment, and prevention of the disease of obesity: reflections from a diabetes care editors' expert forum, Diabetes Care, 2015; 38: $1567-82$.

3.MATSUDA, M., SHIMOMURA, I., Increased oxidative stress in obesity: Implications for metabolic syndrome, diabetes, hypertension, dyslipidemia, atherosclerosis, and cancer, Obesity Research \& Clinical Practice, Volume 7, Issue 5, September-October 2013, Pages e330-e341.

4.RANI, V., DEEP, G., SINGH, R.K., PALLE, K., YADAV, U.C.S., Oxidative stress and metabolic disorders: Pathogenesis and therapeutic strategies, Life Sciences, 2016;148:183-193.

5.LUMENG, C.N., SALTIEL, A.R., Inflammatory links between obesity and metabolic disease. The Journal of Clinical Investigation, 2011; 121(6):2111-2117.

6.ROBERTS, C.K., SINDHU, K.K., Oxidative stress and metabolic syndrome, Life Sci, 2009, 84:705712.

7.BERLINER, J.A., HEINECKE, J.W., The role of oxidized lipoproteins in atherogenesis, Free RadicBiol Med, 1996, 20:707-7215.

8.HOSSEINI, B., SAEDISOMEOLIA, A., ALLMAN-FARINELLI, M., Association between antioxidant intake/status and obesity: a systematic review of observational studies, Biol Trace Elem Res, 2017; 175:287-97.

9.XU, R., CHEN, C., ZHOU, Y., ZHANG, X., WAN, Y., Fingernail selenium levels in relation to the risk of obesity in Chinese children. A cross-sectional study, Medicine, 2018; 97:9.

10.MARSEGLIA, L., MANTI, S., D'ANGELO, G., et al., Oxidative stress in obesity: a critical component in human diseases, Int J Mol Sci, 2014; 16:378-400.

11.NORDBERG, J., ARNER, S.J.E., Reactive oxygen species, antioxidants and the mammalian thioredoxin system, Free Radical Biology \& Medicine, 2001, 31; 11: 1287- 1312.

12.MARCHIO, P., GUERRA-OJEDA, S., VILA, J.M., ALDASORO, M., VICTOR, V.M., MAURICIO, M.D., Targeting Early Atherosclerosis: A Focus on Oxidative Stress and Inflammation, Oxidative Medicine and Cellular Longevity, 2019, https://doi.org/10.1155/2019/8563845.

13.BRITES, F., MARTIN, M., GUILLAS, I., KONTUSH, A., Antioxidative activity of high-density lipoprotein (HDL): Mechanistic insights into potential clinical benefit, BBA Clin., 2017 Dec; 8: 66-77. 
14.DHINGRA, S., BANSAL, M.P., Hypercholesterolemia and apolipoprotein B expression: Regulation by selenium status, Lipids Health Dis., 2005; 4: 28.

15.JIN, R.C., MAHONEY, C.E., COLEMAN ANDERSON, L., OTTAVIANO, F., CROCE, K., LEOPOLD, J.A., ZHANG, Y.Y., TANG, S.S., HANDY, D.E., LOSCALZO, J., Glutathione peroxidase3 Deficiency Promotes Platelet-Dependent Thrombosis in Vivo, Circulation, 11 May 10; 123(18):196373.

16.KIRSCH, J., SCHNEIDER, H., PAGEL, J.-I. et al., Endothelial dysfunction, and a prothrombotic, proinflammatory phenotype is caused by loss of mitochondrial thioredoxin reductase in endothelium, Arteriosclerosis, Thrombosis, and Vascular Biology, 2016; 36(9):1891-1899.

17.WOJCICKI, J., ROZEWICKA, L., WISZNIEWSKA, B.B., SAMOCHOWIEC, L., JUWIAK, S., KADLUBOWSKA, D., TUSTANOWSKI, S., JUZYSZYN, Z., Effect of selenium andvitamin E on the development of experimental atherosclerosisin rabbits, Atherosclerosis, 1991; 87:9-16.

18.LUBRANO, V., BALZAN, S., Enzymatic antioxidant system in vascular inflammation and coronary artery disease, World J Exp Med, 2015, November 20; 5(4): 218-224.

19.FRIEDEWALD, W.T., LEVY, R.T, FREDRICKSON, D.S., Estimation of the Concentration of LowDensity Lipoprotein Cholesterol in Plasma, Without Use of the Preparative Ultracentrifuge, Clin. Chem., 1972, 18:499 - 502.

20.PAGLIA, D.E., VALENTINE, W.N., 1967. Studies on the quantitative and qualitative characterization of erythrocyte glutathione peroxidase, J. Lab Clin. Med., 70: 158-169.

21.KOSTNER, G., CHENNAMESETTY, I., From bench to bedside, Croatia, 2015, InTechISBN 978 95351 2178-7.

22.WALLDIUS, G., JUNGNER, I., The apoB/apoA-I ratio: a strong, new risk factor for cardiovascular disease and a target for lipid-lowering therapy-a review of the evidence, J Intern Med., 2006; 259:493519. doi: 10.1111/j.1365-2796.2006.0164315.

23.VEGA, G.L., GRUNDY, S.M., Does measurement of apolipoprotein B have a place in cholesterol management?, Arteriosclerosis, 1990; 10:668-671.

24.LEVINSON, S.S., WAGNER, S.G., Measurement of apolipoprotein B-containing lipoproteins for routine clinical laboratory use in cardiovascular disease, Arch Pathol Lab Med., 1992; 116:1350-1354. 25.TWISK, J., GILLIAN-DANIEL, D.L., TEBON, A., WANG, L., HUGH, P., BARRETT, R., ATTIE, A.D., The role of the LDL receptor in apolipoprotein B secretion, J Clin Invest., 2000, 105(4): 521-532. 26.NESS, G.C., LOPEZ, D., CHAMBERS, C.M., NEWSOME, W.P., CORNELIUS, P., LONG, C.A., HARWOOD, H.J., Effects of 1-triiodothyronine and the thyromimetic L-94901 on serum lipoprotein levels and hepatic low-density lipoprotein receptor, 3-hydroxy-3-methylglutaryl coenzyme A reductase and apo A-I gene expression, Biochem Pharmacol. 1998; 56:121-129.

doi: 10.1016/S0006-2952(98)00119-1.

27.MUKHOPADHYAY, D., PLATEROTI, M., ANANT, S., NASSIR, F., SAMARUT, J., DAVIDSON, N.O., Thyroid hormone regulates hepatic triglyceride mobilization and apolipoprotein B messenger ribonucleic acid editing in a murine model of congenital hypothyroidism, Endocrinology, 2003; 144:711-719. doi: 10.1210/en.2002-220741.

28.VANDER GEYTEN, S., BYAMUNGU, N., REYNS, G.E., KUHN, E.R., DARRAS, V.M., Iodothyronine deiodinases and the control of plasma and tissue thyroid hormone levels in hyperthyroid tilapia (Oreochromisniloticus), J Endocrinol., 2005; 184:467-479. doi: 10.1677/joe.1.05986.

29.BECKETT, G.J., MACDOUGAL, D.A., NICOL, F., ARTHUR, J.R., Inhibition of types I and II iodothyronine deiodinase activity in rat liver, kidney and brain produced by selenium deficiency, Biochem J., 1989; 259:887-892.

30.DHINGRA, S., SINGH, U., BANSAL, M.P., Effect of selenium depletion and supplementation on the kinetics of Type-I 5'- iodothyronine deiodinase and T3/T4 in rats, Biol Trace Element Res., 2004; 97:95-104. doi: 10.1385/BTER:97:1:95. 
31.DEFRONZO, R. A., FERRANNINI, E., ZIMMET, P., ALBERTI, G., International Textbook of Diabetes Mellitus, edited by Wiley, India 2015, ISBN 978-0-470-65861-1.

32.LIU, M.L., XU, G., HUANG, Z.Y., ZHONG, X.C., LIU, S.H., JIANG, T.Y., Euthyroid Sick Syndrome and Nutritional Status Are Correlated with Hyposelenemia in Hemodialysis Patients, Int J Artif Organs, $2011 \mathrm{Jul} ; \mathbf{3 4}(7): 577-83$.

33.LEE, Y.S., KIM, A.Y., CHOI, J.W., KIM, M., YASUE, S., SON, H.J., et al., Dysregulation of Adipose Glutathione Peroxidase 3 in Obesity Contributes to Local and Systemic Oxidative Stress, $\mathrm{Mol}$ Endocrinol., September 1, 2008; 22(9): 2176-2189.

34.BAEZ-DUARTE, B.G., ZAMORA-GINEZ, I., MENDOZA-CARRERA, F., RUIZ-VIVANCO, G., TORRES-RASGADO, E., GONZALEZ-MEJIA, M.E. GARCIA-ZAPIEN, A., FLORES-MARTINEZ, S.E., PEREZ-FUENTES, R., Serum Levels of Glutathione Peroxidase 3 in Overweight and Obese Subjects from Central Mexico, Archives of Medical Research, 2012; 43(7):541-54.

35.VAZIRI, N.D., MORADI, H., PAHL, M.V., FOGELMAN, A.M., NAVAB, M., In vitro stimulation of HDL anti-inflammatory activity and inhibition of LDL pro-inflammatory activity in the plasma of patients with end-stage renal disease by an apoA-1 mimetic peptide. Kidney Int., 2009 Aug; 76(4):43744. doi: 10.1038/ki.2009.177. Epub 2009 May 27.

36.ALEHAGEN U, AASETH J., Selenium and coenzyme Q10 interrelationship in cardiovascular diseases--A clinician's point of view, Journal of Trace Elements in Medicine and Biology, 2014 11(31):157-162, DOI: 10.1016/j.jtemb.2014.11.006.

37.GRÖBER U. et al., Important drug-micronutrient interactions: A selection for clinical practice, Critical Reviews in Food Science and Nutrition, 2018, 60(2):257-275;

https://doi.org/10.1080/10408398.2018.1522613

$\overline{\text { Manuscript received: } 6.06 .2020}$ 